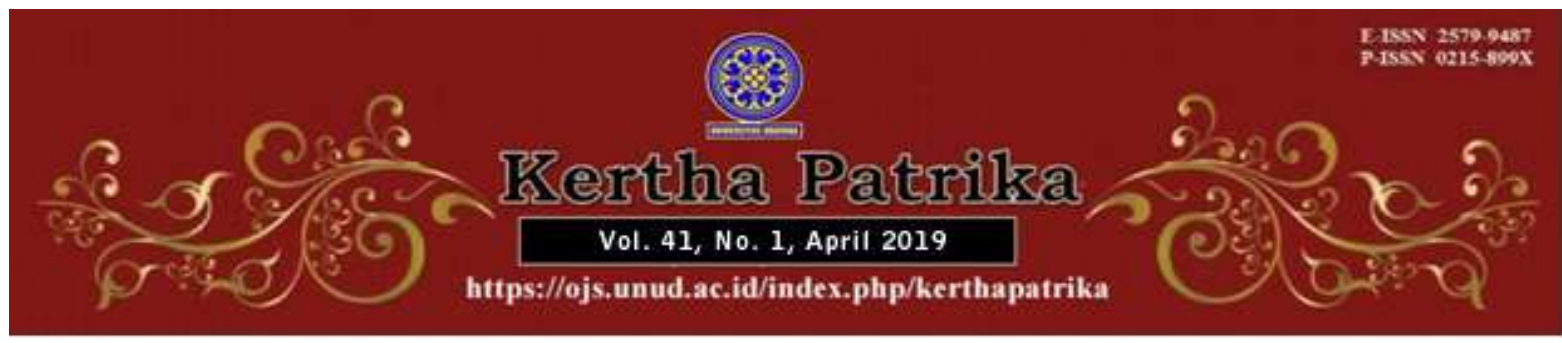

\title{
Penyelenggaraan Pemerintahan Dalam Konteks Negara Hukum Indonesia: Menyoal Signifikansi Pembatalan Peraturan Daerah
}

\section{Nyoman Suyatna ${ }^{1}$}

1Fakultas Hukum Universitas Udayana, E-mail: nyoman_suyatna@unud.ac.id

\begin{tabular}{l}
\hline Info Artikel \\
Masuk : 10 April 2019 \\
Diterima : 28 April 2019 \\
Terbit : 30 April 2019 \\
Keywords : \\
Cancellation; Regional \\
Regulation; Rule of Law; \\
Judicial Review. \\
\\
\\
\\
$\quad$ Hukum; Judicial \\
Kata kunci: \\
Pembatalan; Peraturan Daerah; \\
Negara \\
Review.
\end{tabular}

\begin{abstract}
The many cancellations of regional regulations raise problems regarding the overall governance capacity. This article aims to present an analysis of the administration of government in the context of the rule of law that specifically looks at the authority and significance of the cancellation of the regional regulations. This article applies normative legal research that uses a statutory approach, a case approach, and a conceptual approach. It was concluded that the administration of government in the context of the rule of law is characterized by the respect for the principle of legality in which every government action must be based on the law. Regarding the issue of the cancellation of regional regulations, the Constitutional Court decisions Number 137 / PUU-XIII / 2015 and Number 56 / PUU-XIV / 2016 have clarified the authority to conduct executive review and judicial review.
\end{abstract}

\begin{tabular}{l}
\hline Abstrak \\
\hline Banyaknya pembatalan terhadap peraturan daerah \\
memunculkan persoalan mengenai kapasitas penyelenggaraan \\
pemerintahan secara menyeluruh. Artikel ini bertujuan untuk \\
menyajikan analisis mengenai penyelenggaraan pemerintahan \\
dalam konteks negara hukum Indonesia yang secara khusus \\
mencermati kewenangan dan signifikansi pembatalan peraturan \\
daerah. Artikel ini disusun dengan menggunakan penelitian \\
hukum normatif yang menggunakan pendekatan peraturan \\
perundang-undangan, pendekatan kasus, dan pendekatan \\
konsep. Disimpulkan bahwa penyelenggaraan pemerintahan \\
dalam konteks hukum hukum Indonesia bercirikan \\
penghormatan terhadap asas legalitas yang mana setiap tindakan \\
pemerintah harus berdasarkan atas hukum. Mengenai isu \\
pembatalan peraturan daerah, Putusan Mahkamah Konstitusi \\
Putusan MK Nomor $137 /$ PUU-XIII/2015 dan Nomor 56/PUU- \\
XIV/2016 telah memperjelas kewenangan untuk melakukan \\
executive review dan judicial review.
\end{tabular}




\section{Pendahuluan}

Pasca era pasca otonomi daerah, dinamika penyelenggaraan pemerintahan masih kerap diwarnai oleh diskursus mengenai batas kewenangan antara Pemerintah Pusat dan Pemerintah Daerah. Praktik kehidupan bernegara juga mengindikasikan gerakan pendulum yang relatif dinamis: terkadang mempertontonkan keinginan pemerintah daerah untuk semakin memperjuangkan otonomi seluas-luasnya dan tidak jarang pula mengisyaratkan keinginan kuat pemerintah pusat untuk memberikan determinasi kepada pemerintah daerah dalam kerangka Negara Kesatuan Republik Indonesia (NKRI).

Konstitusi Indonesia sesungguhnya telah secara jelas mengatur perihal kekuasaan pemerintah Negara.Pasal 4 ayat (1) Undang-Undang Dasar Negara Republik Indonesia Tahun 1945 (UUD 1945) menentukan bahwa Presiden memegang kekuasaan Pemerintahan menurut Undang-undang Dasar. Mengenai pemerintahan daerah, Pasal 18 UUD NRI 1945 menggariskan bahwa Pemerintahan daerah provinsi, daerah kabupaten, dan kota mengatur dan mengurus sendiri urusan pemerintahan menurut asas otonomi dan tugas pembantuan. Selanjutnya ditentukan bahwa Pemerintahan daerah menjalankan otonomi seluas-luasnya, kecuali urusan pemerintahan yang oleh undang-undang ditentukan sebagai urusan Pemerintah Pusat. Ketentuan pasal ini juga menggariskan bawa Pemerintahan daerah berhak menetapkan peraturan daerah dan peraturan-peraturan lain untuk melaksanakan otonomi dan tugas pembantuan.

Sejumlah persoalan justru muncul sehubungan dengan kewenangan pemerintah daerah, khususnya kabupaten/kota, dalam menetapkan peraturan daerah. Euforia otonomi daerah ternyata menggiring para kepala daerah dan Dewan Perwakilan Rakyat Daerah (DPRD) untuk membentuk peraturan daerah yang dikehendaki, namun terkadang bertentangan dengan peraturan perundang-undangan yang lebih tinggi. Problematika ketatanegaraan kemudian menyeruak saat pemerintah pusat mengeluarkan kebijakan untuk membatalkan berbagai peraturan daerah. Pada minggu kedua bulan Juni 2016, Pemerintah Pusat mengumumkan dilakukannya pembatalan sebanyak 3.143 peraturan daerah (Perda) dan peraturan kepala daerah (Perkada) yang dianggap menghambat pertumbuhan ekonomi daerah, memperpanjang jalur birokrasi, menghambat proses perizinan dan investasi, menghambat kemudahan berusaha, serta bertentangan dengan peraturan perundangan yang lebih tinggi. ${ }^{1}$ Selain itu, pembatalan juga dilakukan karena ada Perda dan Perkada yang dirasa tidak perlu karena merupakan norma awam yang berlaku di masyarakat. ${ }^{2}$

Kontroversi kembali muncul pasca Mahkamah Konstitusi (MK) mengeluarkan putusan uji materiil Nomor 56/PUU-XIV/2016 dan Nomor 137/PUU-XIII/2015 yang meniadakan kewenangan Pemerintah Pusat untuk membatalkan peraturan daerah kabupaten/kota. MK berpandangan bahwa kewenangan pembatalan dalam konteks judicial review hanyalah dimiliki oleh Mahkamah Agung (MA).

\footnotetext{
1 Fabian Januarius Kuwado."Jokowi: 3.143 Perda Bermasalah Telah Dibatalkan". Available fromhttps://nasional.kompas.com/read/2016/06/13/17215521/jokowi.3.143.perda.bermasal ah.telah.dibatalkan. (Diakses 13 Juni 2016).

2 Leo Agustino. 2017. Pembatalan 3.143 Peraturan Daerah: Satu Analisis Singkat. CosmoGov, 3(1). doi: https://doi.org/10.24198/cosmogov.v3i1.12405, h. 16.
} 
Artikel ini bertujuan untuk menyajikan analisis mengenai penyelenggaraan pemerintahan dalam konteks negara hukum Indonesia yang secara khusus mencermati kewenangan dan signifikansi pembatalan Perda. Sejumlah penelitian memiliki bahasan yang relatif mendekati topik utama artikel ini, kendatipun disajikan dengan perspektif yang beragam. Sebagai contoh, Sugeng Santoso melakukan kajian mengenai interaksi politik yang berlangsung dalam proses pembentukan Perda di era demokrasi serta menawarkan konsep ideal proses pembentukan Perda dalam perspektif demokrasi. ${ }^{3}$ Selanjutnya, Akhmad Khalimy melakukan penelitian terhadap sinkronisasi hukum yang membahas prosedur yang seharusnya dipergunakan pemerintah dalam penghapusan Perda dan menyajikan tinjauan negara hukum terhadap penghapusan perda oleh Pemerintah/Mendagri. ${ }^{4}$ Selain itu dapat pula dirujuk Muhammad Reza Winata, Mery Christian Putri, dan Zaka Firma Aditya yang melakukan penelitian hukum normatif yang menjelaskansejarah hukum pengaturan kewenangan pengujian dan pembatalan Perda serta implikasi Putusan No. 137/PUUXIII/2015 dan Putusan No. 56/PUU-XIV/2016 terhadap kemudahan berusaha di Indonesia. ${ }^{5}$

\section{Metode Penelitian}

Artikel ini disusun dengan menggunakan metode penelitian hukum normatif yang menggunakan pendekatan peraturan perundang-undangan (statutory approach), pendekatan kasus (case approach), dan pendekatan konsep (conceptual approach). Pendekatan peraturan perundang-undangan digunakan untuk membahas bahan hukum primer yakni UUD NRI Tahun 1945 dan sejumlah peraturan perundangundangan terkait, sedangkan pendekatan kasus digunakan untuk membahas kasus/perkara yang diputuskan baik oleh Mahkamah Konstitusi maupun Mahkamah Agung. Adapun pendekatan konsep digunakan untuk menyajikan analisis mengenai konsep negara hukum, otonomi daerah, pembentukan peraturan perundangundangan, dan uji materi. Artikel ini merupakan pengembangan lebih lanjut dari sebagian isi paper yang disusun dan telah dipresentasikan oleh penulis ${ }^{6}$ yang telah direkonstruksi, diberikan sejumlah penambahan substansi serta diberikan pembaruan referensi.

3 Santoso, S. (2014). Pembentukan Peraturan Daerah Dalam Era Demokrasi. Refleksi Hukum: Jurnal Ilmu Hukum, 8(1). doi: https://Doi.Org/Https://Doi.Org/10.24246/Jrh.2014.V8.I1.P1-18, h. 4.

4 Akhmad Khalimy. (2017). Pencabutan Peraturan Daerah Dalam Timbangan Negara Hukum, Mahkamah, 2(1), doi: http://Dx.Doi.Org/10.24235/Mahkamah.V2i1.1617, h. 34,

5 Muhammad Reza Winata, Mery Christian Putri, \& Zaka Firma Aditya. Legal Historis Kewenangan Pengujian Dan Pembatalan Peraturan Daerah Serta Implikasinya Terhadap Kemudahan Berusaha. Jurnal Rechtsvinding, 7(3), 335-352. h. 339.

6 I Nyoman Suyatna, "Penyelenggaraan Pemerintahan Yang Baik Dan Demokratis Dalam Konteks Negara Hukum Indonesia", Paper disampaikan dalam Focus Group Discussion Kelompok Kerja Analisis dan Evaluasi Hukum Terkait Tata Kelola Pemerintahan, dengan tema: "Tata Kelola Pemerintahan yang Efektif, Efisien, Transparan, Akuntabel dan Demokratis, diselenggarakan oleh Pusat Analisis dan Evaluasi Hukum Nasional, Badan Pembinaan Hukum Nasional Kementerian Hukum dan HAM bekerjasama dengan Kantor Wilayah Kementerian Hukum dan HAM Provinsi Bali, pada hari Kamis, 28 Maret 2019, di Hotel Grand Inna Kuta, Bali 


\section{Hasil dan Pembahasan}

\subsection{Konsep Negara Hukum}

Indonesia merupakan negara hukum yang pemerintahannya diselenggarakan oleh pemerintah pusat dan pemerintah daerah. Undang Undang Dasar Negara Republik Indonesia Tahun 1945 (selanjutnya disebut UUD 1945) menentukan dalam Pasal 1 ayat (1) bahwa "Indonesia adalah Negara Kesatuan yang berbentuk Republik". Selanjutnya Pasal 18 ayat (1) UUD 1945 menentukan bahwa "Negara Kesatuan Republik Indonesia dibagi atas daerah-daerah provinsi dan daerah provinsi itu dibagi atas kabupaten dan kota, yang tiap-tiap provinsi, kabupaten dan kota itu mempunyai pemerintahan daerah yang diatur dengan undang-undang". Pemberian penyelenggaraan pemerintahan daerah kepada daerah provinsi, kabupaten, dan kota mencerminkan pemerintahan Negara Kesatuan Republik Indonesia dilaksanakan berdasarkan asas desentralisasi. ${ }^{7}$ Dalam penyelenggaraan desentralisasi, pemerintahan daerah diberikan kewenangan untuk mengatur dan mengurus sendiri urusan pemerintahan, dengan kata lain, daerah diberikan otonomi daerah.

A. Mukthie Fadjar mengatakan, suatu negara merupakan negara hukum atau bukan, dapat dilihat dalam konstitusi negara tersebut, apakah ada penegasan, baik secara eksplisit maupun implisit yang menyatakan dirinya sebagai suatu negara hukum. ${ }^{8}$ Sejak awal UUD 1945 telah menjelaskan bahwa: "Negara Indonesia berdasar atas hukum (rechtsstaat), tidak berdasarkan atas kekuasaan belaka (machtsstaat)". Pasca amandemen terhadap UUD 1945, Pasal 1 ayat (3) Undang-Undang Dasar Negara Republik Indonesia Tahun 1945 (selanjutnya disebut UUD 1945) secara tegas menyatakan bahwa Indonesia merupakan negara hukum. Negara hukum Indonesia merupakan negara hukum material atau negara hukum dalam arti luas. Bentuk ini dikenal juga dengan istilah negara hukum modern atau negara kesejahteraan (welfare state) yaitu suatu negara yang bertugas menjaga keamanan dalam arti kata seluasluasnya, yaitu keamanan sosial (social security) dan menyelenggarakan kesejahteraan umum, berdasarkan prinsip-prinsip hukum yang benar dan adil sehingga hak-hak asasi warga negaranya benar-benar terjamin dan terlindungi. ${ }^{9}$

Makna negara hukum akan hilang apabila diselenggarakan tanpa demokrasi dan demokrasi akan kehilangan bentuk dan arah apabila tanpa diikuti pengaturan hukum. ${ }^{10}$ Frans Magnis Suseno menjelaskan tentang hubungan demokrasi dengan negara hukum dengan menyebutkan, demokrasi merupakan cara paling aman untuk mempertahankan kontrol atas negara hukum, sehingga demokrasi yang bukan negara hukum bukan demokrasi dalam arti yang sesunguhnya. ${ }^{11}$ Dengan mengakomodasi

7 Fahmi Amrusyi. (1987). Otonomi Dalam Negara Kesatuan. Abdurrahman (Ed.). Jakarta: Media Sarana Press. h. 56.

8 A. Mukthie Fadjar. (2004). Penyelenggaraan Pemerintahan yang Baik dan Demokratis dalam Konteks Negara Hukum Indonesia Tipe Negara Hukum. Cetakan Pertama. Malang: Bayumedia Publishing. h. 83.

9 Ibid., h. 36.

10 Ridwan, H. R. (2006). Hukum Administrasi Negara. Jakarta: Raja Grafindo Persada. h. 8

11 Frans Magnis Suseno. (1997). Mencari Sosok Demokrasi - Sebuah Telaah Filosofis. Jakarta: Gramedia, h. 58-59. 
kedua prinsip tersebut, maka negara hukum yang bertumpu pada demokrasi dapat disebut sebagai negara hukum demokratis (democratische rechtsstaat). ${ }^{12}$

Negara hukum demokratis mengakomodasi prinsip-prinsip negara hukum dan prinsip-prinsip demokrasi, yang dijalankan secara beriringan sebagai dua sisi dari satu mata uang..$^{13}$ Dalam negara hukum demokratis, hukum tidak boleh dibuat, ditetapkan, ditafsirkan, dan ditegakkan hanya berdasarkan kekuasaan semata (machtsstaat), sebaliknya demokrasi harus diatur berdasarkan atas hukum. Perihal negara hukum demokratis tersebut, Andi Mattalata ${ }^{14}$ sebagai mantan Menteri Hukum dan Hak Asasi Manusia mengatakan bahwa UUD 1945 menganut prinsip bahwa Negara Republik Indonesia adalah negara hukum yang demokratis dan sekaligus negara demokrasi yang berdasarkan atas hukum.

Sebagai negara hukum yang demokratis, maka penyelenggaraan pemerintahan baik di pusat maupun di daerah harus diselenggarakan berdasarkan prinsip-prinsip negara hukum dan pemerintahan yang demokratis. Salah satu ciri yang dipersyaratkan dalam negara hukum yaitu asas legalitas, yang menekankan pada setiap tindakan, baik yang dilakukan oleh pemerintah maupun masyarakat harus berdasarkan atas hukum. Dalam tataran negara hukum terlihat ada pembatasan terhadap kebebasan dalam melakukan tindakan dan segala tindakan harus tunduk kepada hukum. Hal demikian sesuai dengan pandangan F.R. Bothlingk, yang menyebutkan bahwa negara hukum adalah negara yang kebebasan kehendak pemegang kekuasaan dibatasi oleh ketentuan hukum ${ }^{15}$. Burkens juga mengemukakan hal senada, bahwa negara hukum secara sederhana adalah negara yang menempatkan hukum sebagai dasar kekuasaan negara dan penyelenggaraan kekuasaan tersebut dalam segala bentuknya dilakukan di bawah kekuasaan hukum. ${ }^{16}$ Sedangkan pemerintahan yang demokratis adalah pemerintahan dari, oleh dan untuk rakyat, sesuai dengan konsep sistem pemerintahan yang bila ditelusuri sejarahnya mulai diterapkan di Yunani yang dalam literatur terkadang disebut dengan istilah "demokrasi primitif" atau "demokrasi kesukuan" (tribal democracy). ${ }^{17}$ Dengan demikian, maka partisipasi atau peran serta masyarakat dalam penyelenggaraan pemerintahan sangat penting sebagai perwujudan dari pemerintahan yang demokratis.

\subsection{Hubungan Pemerintahan Pusat dan Pemerintahan Daerah dalam Penyelenggaraan Pemerintahan Yang Baik dan Demokratis: Pentingnya Pembentukan Peraturan Daerah}

Dalam penyelenggaraan pemerintahan, pemerintahan daerah diberikan kewenangan untuk mengatur dan mengurus sendiri urusan pemerintahan, dengan

12 Ridwan, H. R. Op. cit. h. 8-9.

13 Jimly Asshidiqqie. (2009). Menuju Negara Hukum Yang Demokratis. Jakarta: Bhuana Ilmu Populer. h. 398.

14 Satjipto Rahardjo, 2008, UUD 1945 Sebagai Landasan Grand Design Sistem Dan Politik Hukum Nasional, Pokok-Pokok Pikiran Penyaji - Sesi II, Dalam "Konvensi Hukum Nasional Tentang Undang-Undang Dasar 1945 Sebagai Landasan Konstitusional Grand Design System Dan Politik Hukum Nasional", Diselenggarakan Oleh Badan Pembinaan Hukum Nasional Departemen Hukum Dan HAM, Jakarta, 15-16 April 2008, h. 24.

15 Ridwan H. R. Op.cit. h. 18.

16 A. Hamid S. Attamimi. (1992). Teori Perundang-Undangan Indonesia, "Pidato" Pada Upacara Pengukuhan Jabatan Guru Besar Tetap Di Fakultas Hukum UI, Jakarta, 25 April 1992, h. 8.

17 Munir Fuady. (2010). Konsep Negara Demokrasi. Bandung: Refika Aditama. h. 76. 
kata lain, daerah diberikan otonomi daerah. Sebagaimana dijelaskan dalam Pasal 1 angka 6 Undang-Undang No. 23 Tahun 2014 tentang Pemerintahan Daerah (selanjutnya disebut UU Pemda) otonomi daerah adalah hak, wewenang, dan kewajiban daerah otonom untuk mengatur dan mengurus sendiri urusan pemerintahan dan kepentingan masyarakat setempat dalam sistem Negara Kesatuan Republik Indonesia. Penjelasan Umum angka I.1 UU Pemda menegaskan, pemerintahan daerah berwenang mengurus sendiri urusan pemerintahan menurut asas otonomi dan tugas pembantuan dan diberikan otonomi yang seluas-luasnya. Pemberian otonomi seluas-luasnya kepada Daerah diarahkan untuk mempercepat terwujudnya kesejahteraan masyarakat melalui peningkatan pelayanan, pemberdayaan, dan peran serta masyarakat. Di samping itu, melalui otonomi luas, dalam lingkungan strategis globalisasi, Daerah diharapkan mampu meningkatkan daya saing dengan memperhatikan prinsip demokrasi, pemerataan, keadilan, keistimewaan, dan kekhususan serta potensi dan keanekaragaman Daerah dalam sistem NKRI. Dalam negara kesatuan, Daerah tidaklah memiliki kedaulatan karena kedaulatan hanya ada pada pemerintahan negara atau pemerintahan nasional. Dijelaskan pula dalam Penjelasan Umum angka I.1 UU Pemda tersebut, dalam rangka memberikan ruang yang lebih luas kepada Daerah untuk mengatur dan mengurus kehidupan warganya maka Pemerintah Pusat dalam membentuk kebijakan harus memperhatikan kearifan lokal. Sebaliknya, ketika Daerah membentuk kebijakan Daerah hendaknya juga memperhatikan kepentingan nasional. Dengan demikian, akan tercipta keseimbangan antara kepentingan nasional yang sinergis dan tetap memperhatikan kondisi, kekhasan, dan kearifan lokal dalam penyelenggaraan pemerintahan secara keseluruhan.

Berdasarkan penjelasan ketentuan di atas dapat dilihat bahwa pemberian otonomi kepada Daerah dimaksudkan untuk mewujudkan kesejahteraan rakyat, serta meningkatkan daya saing daerah dengan memperhatikan prinsip demokrasi, pemerataan, keadilan, keistimewaan dan kekhususan suatu Daerah dalam sistem negara kesatuan. Kebijakan dalam penyelenggaraan pemerintahan pusat diarahkan untuk mewujudkan keseimbangan antara kepentingan nasional yang sinergis dan tetap memperhatikan kondisi, kekhasan, dan kearifan lokal, demikian juga kebijakan Daerah baik dalam bentuk Perda maupun kebijakan lainnya harus memperhatikan kepentingan nasional dalam penyelenggaraan pemerintahan dalam prinsip negara kesatuan.

Dalam Pasal 18 ayat (6) UUD 1945 dapat dilihat bahwa untuk melaksanakan otonomi daerah dan tugas pembantuan, pemerintahan daerah memiliki kewenangan untuk menetapkan Perda. Hal senada ditentukan Pasal 236 UU Pemda, bahwa pembentukan Perda dilakukan oleh pemerintahan daerah dalam rangka menyelenggarakan otonomi daerah dan tugas pembantuan, dan Perda tersebut dibentuk oleh DPRD dengan persetujuan bersama kepala Daerah. Dengan demikian dapat dikatakan, Perda merupakan landasan bagi pemerintahan daerah untuk melaksanakan otonomi daerah. Dalam kaitan ini, An Seidman et.al. ${ }^{18}$ mengatakan bahwa peraturan perundangundangan (termasuk Perda) merupakan pernyataan efektif dari kebijakan. Kebijakankebijakan pejabat pemerintahan harus diterjemahkan ke dalam peraturan perundang-

18 Seidman, Ann, et.al. (2002). Penyusunan Rancangan Undang-Undang Dalam Perubahan Masyarakat Yang Demokratis: Sebuah Panduan untuk Pembuat Rancangan Undang-undang. Diterjemahkan oleh: Yohanes Usfunan, dkk. Edisi Kedua, Proyek Elips II, Jakarta: Departemen Kehakiman dan HAM Republik Indonesia. h. 14. 
undangan dan harus dilaksanakan oleh pejabat negara yang lain. Dijelaskan juga, ${ }^{19}$ bahwa dalam konsep perancangan peraturan perundangan, "pemegang peran" (role occupant) dan "lembaga pelaksana" (implementing agency) merupakan dua komponen yang sangat berperan terhadap keefektifan berlakunya suatu peraturan perundang-undangan, walaupun di luar itu juga ada faktor-faktor lain yang dapat mempengaruhi keberlakuannya. Pembentukan peraturan perundang-undangan ditujukan untuk dapat merubah prilaku para pemegang peranan atau para pihak yang dikenai oleh peraturan perundang-undangan, sehingga prilakunya sejalan dengan norma-norma yang digariskan dalam peraturan yang baru. Demikian juga pihak lembaga pelaksana ketentuan, berdasarkan atas peraturan perundang-undangan yang ditetapkan, dituntut untuk melaksanakan fungsinya terutama dalam menegakkan peraturan perundang-undangan (law enforcement) tersebut.

Kewenangan pembentukan Perda oleh pemerintahan daerah harus dilakukan secara baik dan dapat mencerminkan keadilan bagi semua lapisan masyarakat, seperti yang dikemukakan oleh tokoh dalam filfasat hukum yang menganut aliran utilitarianisme, Jeremy Bentham, bahwa para pembentuk undang-undang hendaknya dapat melahirkan undang-undang yang mencerminkan keadilan bagi semua individu, serta dapat memberikan kebahagiaan yang terbesar bagi sebagian besar masyarakat (the greatest happiness for the greatest number). ${ }^{20}$

Tindakan pembentukan Perda tersebut bila dikaitkan dengan teori dalam hukum administrasi negara yang berlandaskan pada negara hukum dan demokrasi, maka para pejabat pemerintahan yang memiliki kewenangan di bidang pembentukan Perda tidak dapat melakukannya secara sewenang-wenang. Dalam kerangka negara hukum, wewenang pemerintah bersumber dari peraturan perundang-undangan yang berlaku. ${ }^{21}$ Di samping itu, pemerintah harus memberikan kesempatan kepada masyarakat untuk berpartisipasi dalam proses pengaturan dan pengendalian, serta sekaligus memberikan pengayoman atau perlindungan hukum kepada masyarakat. Dengan demikian, pembentukan Perda yang demokratis dan partisipatif sesungguhnya sejalan dengan gagasan negara hukum serta merupakan wujud pelaksanakan otonomi daerah dan tugas pembantuan dalam konteks hubungan antara pemerintahan pusat dan pemerintahan daerah dalam penyelenggaraan pemerintahan yang baik.

\subsection{Menyoal Signifikansi Pembatalan Peraturan Daerah}

Sebagaimana dibahas pada bagian pendahuluan artikel ini, salah satu persoalan berkaitan dengan hubungan antara pemerintah pusat dan daerah adalah mengenai kewenangan pemerintah pusat untuk membatalkan Perda. Secara teknis, Pasal 129 dan 130 Peraturan Menteri Dalam Negeri No. 80 Tahun 2015 tentang Pembentukan Produk Hukum Daerah menentukan bahwa pembatalan terhadap Perda Provinsi dapat dilakukan, apabila Perda tersebut dalam kajian yang dilakukan oleh Tim Pembatalan Perda Provinsi yang dibentuk oleh Dirjen Otonomi Daerah atas nama Menteri Dalam

19 Ibid. h. 20.

20 Lili Rasjidi \& Ira Thania Rasjidi. (2002) Pengantar Filsafat Hukum, Bandung,: Mandar Maju. h. 61. Lihat Juga: Mukti Fajar Dan Yulianto Achmad dalam Dualisme Penelitian Hukum: Normatif dan Empiris.

21 Juniarso Ridwan dan Ahmad Sodik Sudrajat. (2009). Hukum Administrasi Negara. Bandung: Nuansa. h. 137 
Negeri, dinyatakan bertentangan dengan peraturan perundang-undangan yang lebih tinggi, kepentingan umum, dan/atau kesusilaan, yang ditetapkan dengan Keputusan Menteri Dalam Negeri tentang Pembatalan Perda Provinsi. Demikian juga terhadap Perda kabupaten/kota, dapat dibatalkan dengan Keputusan Gubernur, apabila Perda tersebut berdasarkan kajian Tim Pembatalan Perda Kabupaten/Kota yang dibentuk oleh Sekretaris Daerah atas nama Gubernur, dinyatakan bertentangan dengan peraturan perundang-undangan yang lebih tinggi, kepentingan umum, dan/atau kesusilaan. Hal ini sesuai dengan Pasal 142 dan 143 Peraturan Menteri Dalam Negeri No. 80 Tahun 2015 tentang Pembentukan Produk Hukum Daerah. ${ }^{22}$

Dalam implementasinya, Mendagri telah mengeluarkan instruksi mengenai pencabutan Perda melalui Instruksi Mendagri Nomor: 582/476/SJ tentang Pencabutan/Perubahan Peraturan Daerah, Peraturan Kepala Daerah, dan Keputusan Kepala Daerah yang Menghambat Birokrasi dan Perizinan Investasi, tanggal 16 Februari 2016. Instruksi ini kembali ditegaskan melalui Instruksi Mendagri Nomor: 582/1107/SJ tentang Penegasan Instruksi Mendagri Nomor: 582/476/SJ tentang Pencabutan/Perubahan Peraturan Daerah, Peraturan Kepala Daerah, dan Keputusan Kepala Daerah yang Menghambat Birokrasi dan Perizinan Investasi, tanggal 4 April 2016.

Dalam konteks mekanisme kontrol norma hukum, pembentukan Perda sebagai bagian dari peraturan perundang-undangan nasional,sesungguhnya tidak terlepas dari 3 (tiga) bentuk pengawasan dan pengendalian yakni mekanisme kontrol yuridis dengan cara judicial review; mekanisme kontrol administratif melalui organ eksekutif atau lembaga administrasi; dan mekanisme kontrol politik yang dilakukan oleh lembaga politik semacam parlemen.23 Mekanisme kontrol kedua, yakni kontrol administratif, sesungguhnya tercermin dalam pemberian kewenangan kepada Mendagri dan Gubernur selaku wakil pemerintah pusat dalam fungsi "bestuur" untuk membatalkan Perda sebagaimana diatur di dalam Pasal 251 UU No. 23 Tahun 2014.24

Dilihat dari sejarah hukum konstitusi Indonesia, kewenangan MA untuk menguji Perda telah diatur semenjak Konsttusi RIS dan diatur kembali pada UUD NRI 1945 pasca amandemen. ${ }^{25}$ Adapun kewenangan Pemerintah Pusat untuk menguji dan membatalkan Perda dalam tingkat konstitusi tidaklah ditemukan secara tegas, tetapi justru dapat ditemukan dalam undang-undang mengenai pemerintahan daerah. ${ }^{26}$

Akhmad Khalimy berpendapat bahwa kewenangan pemerintah (presiden) untuk membatalkan perda tidak sejalan dengan semangat otonomi daerah dan negara hukum serta menyiratkan kekhawatiran terjadinya kesewenang-wenangan. ${ }^{27}$ Dengan

22 Lihat pembahasan selanjutnya yang mengetengahkan substansi Peraturan Menteri Dalam Negeri Republik Indonesia Nomor 120 Tahun 2018 Tentang Perubahan Atas Peraturan Menteri Dalam Negeri Nomor 80 Tahun 2015 Tentang Pembentukan Produk Hukum Daerah

23 Wahyu Tri Hartomo. (2018). Implikasi Putusan Mahkamah Konstitusi Nomor 137/PUUXIII/2015 dan Putusan Nomor 56/PUU-XIV/2016 Tentang Pembatalan Perda Provinsi, Perda Kabupaten/Kota, Peraturan Gubernur, dan Peraturan Bupati/Peraturan Walikota. Jurnal Legislasi Indonesia, 15(2). h. 30.

24 Ibid. h. 31.

25 Muhammad Reza Winata, Mery Christian Putri, \& Zaka Firma Aditya, Op.cit. h. 346.

26 Ibid.

27 Akhmad Khalimy. Op.cit. h. 40. 
demikian, penegakan negara hukum dan pembatalan Perda harus dilakukan dengan kehati-hatian, kecermatan dan kesabaran guna mencegah potensi kegaduhan. ${ }^{28}$

Peraturan Mahkamah Agung Republik IndonesiaNomor 1 Tahun 2011 Tentang Hak Uji Materiil mendefinisikan hak uji materiil sebagai Hak MA untuk menilai materi muatan peraturan perundang-undangan di bawah undang-undang terhadap peraturan perundang-undangan tingkat lebih tinggi. ${ }^{29}$ Mahkamah Konstitusi dalam Putusan Nomor 66/PUU-XIV/2016 menegaskan bahwa dalam konteks produk hukum daerah, Perda dan Peraturan Kepala Daerah (Perkada) dapat diuji dengan peraturan perundang-undangan yang lebih tinggi. ${ }^{30}$ Putusan ini juga memberikan kejelasan bahwa Pasal 31 ayat (2) Undang-Undang Mahkamah Agung memungkinkan Perda diuji dengan Undang-Undang, Peraturah Pemerintah, ataupun Peraturan Presiden tanpa meniadakan substansi yang tertuang di dalam Pasal 24 A ayat (1) UUD NRI Tahun $1945 .{ }^{31}$

Putusan Mahkamah Konstitusi Nomor 137/PUU-XIII/2015 mengadili perkara pengujian UU Nomor 23 Tahun 2014 tentang Pemerintahan Daerah yang diajukan oleh Asosiasi Pemerintahan Kabupaten Seluruh Indonesia (APKASI) et.al. ${ }^{32}$ Dalam putusan tersebut, MK mempertimbangkan prinsip Negara Kesatuan Republik Indonesia, prinsip otonomi daerah, prinsip kekuasaan kehakiman dan negara hukum. ${ }^{33} \mathrm{MK}$ berpendirian bahwa pemberian kewenangan kepada mendagri dan gubernur untuk membatalkan perda kabupaten/kota menyimpangi logika dan bangunan negara hukum Indonesia serta sekaligus meniadakan peran dan fungsi MA selaku institusi yudisial yang berwenang untuk mengadili perkara judicial review terhadap peraturan perundang-undangan di bawah undang-undang. ${ }^{34}$ Selanjutnya, MK memandang bahwa pembatalan Perda Kabupaten/Kota melalui keputusan gubernur selaku wakil Pemerintah Pusat berdasarkan Pasal 251 ayat (4) UU Pemda tidak sesuai dengan rezim peraturan perundang-undangan Indonesia karena Pasal 7 ayat (1) dan Pasal 8 UU Nomor 12 tahun 2011 tentang Pembentukan Peraturan Perundang-undangan tidak menyebut Keputusan Gubernur sebagai jenis dan hierarki peraturan perundangundangan. Selain itu, MK juga mencermati terjadi kekeliruan karena Perda Kabupaten/Kota yang bersifat regeling justru dibatalkan oleh keputusan gubernur yang bersifat beschikking. ${ }^{35}$ Putusan ini tidaklah menegasikan kewenangan Mendagri dan Gubernur karena kontrol gubernur dan Mendagri sebagai wakil pemerintah pusat tetap bisa dilakukan melalui evaluasi Rancangan Perda Kabupaten/Kota (executive preview). ${ }^{36}$

Putusan tersebut ternyata diambil tanpa suara bulat karena empat hakim, yakni Arief Hidayat, I Dewa Gede Palguna, Maria Farida Indrati, dan Manahan MP Sitompul,

28 Ibid. h. 41.

29 Pasal 1 Ayat (1) Peraturan Mahkamah AgungRepublik IndonesiaNomor 1 Tahun 2011 Tentang Hak Uji Materiil

30 Putusan Mahkamah Konstitusi Nomor 66/PUU-XIV/2016, [3.11.6]. 5.B., h.131

31 Ibid, [3.11.6]. 5.C

32 Putusan Mahkamah Konstitusi Nomor 137/PUU-XIII/2015, [1.1], h.1-11.

33 Ibid. [3.12.3], h.196-204.

34 Ibid. [3.12.4], h.205

35 Ibid. h.205-206.

36 Hukumonline. MK Tegaskan Mendagri Masih Boleh Batalkan Perda Provinsi. Available from https://Www.Hukumonline.Com/Berita/Baca/Lt58eb3eaf51dd2/Mk-TegaskanMendagri-Masih-Boleh-Batalkan-Perda-Provinsi, (Diakses 10 April 2017). 
ternyata mengekspresikan pendapat berbeda (dissenting opinion). Keempat hakim tersebut mendalilkan bahwa kewenangan kepala daerah dan Dewan Perwakilan Rakyat Daerah untuk membentuk Perda merupakan kewenangan atribusi yang diberikan berdasarkan Pasal 18 (6) UUD NRI 1945 dan Pasal 236 UU Pemda serta menegaskan bahwa Perda bukanlah peraturan delegasi dari UU Pemda. ${ }^{37 D i s s e n t i n g}$ Opinion tersebut juga mengetengahkan pandangan bahwa pembatalan menurut Hukum Administrasi pada hakikatnya merupakan suatu tindakan hukum yang diambil dalam hal keputusan yang dibuat oleh pejabat pemerintahan memuat catat hukum atau tidak lagi memenuhi syarat fromal maupun substantif yang bertujuan untuk melindungi pihak-pihak yang dirugikan oleh keputusan pemerintah serta untuk memulihkan kembali atau meniadakan akibat hukum keputusan tersebut. 38

Adapun Putusan MK Nomor 56/PUU-XIV/2016 banyak menyitir substansi yang termuat di dalam Putusan Mahkamah Konstitusi Nomor 137/PUU-XIII/2015, khususnya berkenaan dengan peraturan kepala daerah, ${ }^{39}$ peraturan daerah, ${ }^{40}$ dissenting opinion dari keempat hakim. ${ }^{41}$

Sejumlah kalangan merespon putusan tersebut. Wahyu Tri Hartomo berpandangan bahwa pasca putusan MK tersebut, praktis kewenangan pemerintah pusat terhadap Perda Provinsi dan Perda Kabupaten/Kota terbatas hanya pada bentuk pengawasan preventif, yakni pemberlakuan tiap peraturan daerah yang mengatur persoalanpersoalan tertentu, terlebih dahulu mendapatkan persetujuan dari Menteri Dalam Negeri. ${ }^{42}$ Eka N A M Sihombing memandang bahwa Putusan MK Nomor 137/ PUUXIII/2015 dan Nomor 56/PUU-XIV/2016 tidaklah serta merta menyelesaikan permasalahan konstitusionalitas kewenangan pengujian terhadap produk hukum daerah karena Mendagri masih memiliki kewenangan untuk membatalkan peraturan gubernur serta gubernur masih dapat membatalkan peraturan bupati/wali kota, ${ }^{43}$ yang kenyataannya saat ini diatur di dalam Pasal 129 dan Pasal 142 Peraturan Menteri Dalam Negeri Republik Indonesia Nomor 120 Tahun 2018 Tentang Perubahan Atas Peraturan Menteri Dalam Negeri Nomor 80 Tahun 2015 Tentang Pembentukan Produk Hukum Daerah. Eka N A M Sihombing selanjutnya berpendapat bahwa pembatalan peraturan gubernur maupun peraturan bupati/wali kota juga seharusnya dilakukan melalui mekanisme hak uji materiil di MA. ${ }^{44}$ Pada intinya, pemerintah, dalam hal ini Mendagri, dipandang bukanlah lembaga yang tepat dalam melakukan pembatalan perda, karena kewenangan dalam pembatalan perda. ${ }^{45}$

Yuswanto dan M. Yasin Al Arif mengemukakan adanya dikotomi dan dualisme pengujian Perda, yakni melalui executive review oleh Pemerintahdan judicial review oleh MA disebabkan karena UUD NRI Tahun 1945 tidak menjelaskan secara detail lembaga

37 Ibid. h. 214.

38 Ibid. h. 215.

39 Putusan Mahkamah Konstitusi Nomor 56/PUU-XIV/2016, [3.9.1], h.96-67.

40 Ibid,. [3.9.2], h.98-99.

41 Ibid. [3.11], h.100.

42 Wahyu Tri Hartomo. Op.cit. h. 37.

43 Eka N. A. M. Sihombing. (2017). Perkembangan Kewenangan Pembatalan Peraturan Daerah Dan Peraturan Kepala Daerah: Kajian Putusan Mahkamah Konstitusi Nomor 137/PUUXIII/2015 dan Nomor 56/PUU-XIV/ 2016. Jurnal Yudisial, 10(2). h. 230-232.

$44 \quad$ Ibid. h. 232.

45 Novira Maharani Sukma. (2017). Analisis Yuridis Pembatalan Perda oleh Menteri Dalam Negeri. Jurnal Ilmiah Galuh Yustisi, 5(1). h. 20. 
yang memiliki kewenangan untuk menguji Perda. ${ }^{46}$ Adapun Pasal 18 ayat (6) hanyalah menyatakan bahwa "pemerintah daerah berhak menetapkan peraturan daerah dan peraturan lain untuk melaksanakan otonomi daerah dan tugas pembantuan". Terhadap kedua putusan MK yang mengakhiri dualisme pengujian Perda, mereka berpandangan bahwa walaupun secara teoritis kedua lembaga memperoleh dasar yang logis, namun secara yuridis kewenangan MA memiliki dasar yang lebih kuat karena secara eksplisit disebutkan di dalam Pasal 24A ayat (1) UUD NRI Tahun 1945, dibandingkan Pemerintah yang hanya memperoleh kewenangan berdasarkan UU Pemerintah Daerah. ${ }^{47}$

Secara prinsipiil, Presiden, melalui salah satu Staf Khusus-nya, menyatakan menghormati putusan tersebut. ${ }^{48}$ Sebagai implementasi atas kedua putusan MK tersebut, pemerintah melalui Menteri Dalam Negeri telah menerbitkan Peraturan Menteri Dalam Negeri Republik Indonesia Nomor 120 Tahun 2018 Tentang Perubahan Atas Peraturan Menteri Dalam Negeri Nomor 80 Tahun 2015 Tentang Pembentukan Produk Hukum Daerah. Kendatipun demikian, Menteri Dalam Negeri (Mendagri) sempat menyampaikan keheranannya atas putusan MK yang menganulir kewenangannya untuk menghapuskan perda karena akan berimplikasi pada program pemerintah seperti misalnyaterhambatnya program deregulasi untuk investasi secara terpadu antara pemerintah pusat dan daerah. Selain itu, Mendagri juga menyangsikan akselerasi Mahkamah Agung untuk membatalkan Perda dalam waktu singkat. ${ }^{9}$ Pandangan Mendagri nampaknya didasari oleh fakta karena data tahun 2016, yakni setahun sebelum putusan MK tersebut dikeluarkan, menunjukkan bahwa Mahkamah Agung (MA) hanya mampu menangani 8 (delapan) perkara mengenai perda dari total 49 (empat puluh sembilan) perkara..$^{50}$

Kekhawatiran mengenai kecepatan MA dalam menangani perkara uji materi Perda tentu hanya dibuktikan oleh kinerja MA. Sebagai salah satu contoh, dapat dirujuk Putusan Mahkamah Agung Nomor: 64 P/HUM/2017 yang mengadili judicial review terhadap Pasal 41 ayat (2) Huruf g angka 31 Peraturan Daerah Kota Depok Nomor 1 Tahun 2015 tentang Rencana Tata Ruang Wilayah Kota Depok Tahun 2012-2032. Permohonan uji materi perkara ini diterima di Kepaniteraan MA pada tanggal 25 Oktober 2017,51 yang direspon melalui jawaban tertulis oleh Termohon pada tanggal 20 November 2017.52 Putusan akhirnya ditetapkan dalam rapat permusyawaratan

46 Yuswanto \& M. Yasin Al Arif, Diskursus Pembatalan Peraturan Daerah Pasca Putusan MK No. 137/PUU-XIII/2015 dan No. 56/PUU-XIV/2016. Jurnal Konstitusi, 15(4), 710-731. doi: https://doi.org/10.31078/jk1542. h. 719.

47 Ibid. h. 724.

48 Imanuel Nicolas Manafe. (2017). Pemerintah Hormati Putusan MK Terkait Kewenangan Pencabutan Perda. Available from http://www.Tribunnews.Com/Nasional/2017/04/07/Pemerintah-Hormati-Putusan-MkTerkait-Kewenangan-Pencabutan-Perda. (Diakses 7 April 2017).

49 Lutfy Mairizal Putra. Tjahjo Tak Habis Pikir MK Cabut Kewenangan Mendagri Batalkan Perda. Available from https://Nasional.Kompas.Com/Read/2017/04/06/10561981/Tjahjo.Tak.Habis.Pikir.Mk.Ca but.Kewenangan.Mendagri.Batalkan.Perda. (Diakses 6 April 2017).

50 M. Nur Sholikin. (2017). Penghapusan Kewenangan Pemerintah Untuk Membatalkan Perda; Momentum Mengefektifkan Pengawasan Preventif dan Pelaksanaan Hak Uji Materiil MA, Rechtsvinding Online (12 Mei 2017), h. 4.

51 Putusan Mahkamah Agung Nomor: 64 P/HUM/2017, h. 2.

52 Ibid. h. 64. 
Mahkamah Agung dan diucapkan dalam sidang terbuka untuk umumpada tanggal 30 November 2017.53 Jika mencermati jangka waktu penyelesaian perkara ini, maka terlihat bahwa judicial review terhadap perda dapat diadili selama sekitar 5 (lima) minggu oleh MA. Contoh lain di tahun 2018 dapat dilihat pada Putusan Mahkamah Agung Nomor: 66 P/HUM/2018 mengenai permohonan keberatan hak uji materiil terhadap Peraturan Daerah Kota Metro Nomor 9 Tahun 2017 Tentang Ketertiban Umum, Kebersihan dan Keindahan. Permohonan oleh Pemohon diterima di Kepaniteraan MA pada tanggal 26 September 2018,54 yang dijawab secara tertulis oleh Termohon Walikota Metro pada tanggal 24 Oktober 2018.55 Putusan kemudian diucapkan pada 17 Desember 2018.56 Dalam perkara ini, MA memeriksa dan mengadilinya dalam rentang waktu kurang dari 3 (tiga) bulan.

\section{Kesimpulan}

Penyelenggaraan pemerintahan dalam konteks negara hukum Indonesia, termasuk mencakup hubungan antara pemerintahan pusat dan daerah, bercirikan penghormatan terhadap asas legalitas. Dengan demikian, setiap tindakan pemerintah harus berdasarkan atas hukum. Pembentukan Peraturan Daerah (Perda) yang demokratis dan partisipatif sesungguhnya sejalan dengan gagasan negara hukum serta merupakan wujud pelaksanakan otonomi daerah dan tugas pembantuan dalam konteks hubungan antara pemerintahan pusat dan pemerintahan daerah dalam penyelenggaraan pemerintahan yang baik. Dalam tataran negara hukum tercermin adanya pembatasan terhadap kebebasan dalam melakukan tindakan dan segala tindakan harus tunduk kepada hukum. Berangkat dari konsep ini, pemerintah daerah tidaklah memiliki kewenangan absolut dalam pembentukan peraturan daerah. Adanya pembatasan bagi pemerintah daerah, baik dalam hal materi maupun prosedur pembentukan Perda, tentu linier dengan konsep negara hukum. Juga menjadi konsekuensi logis bahwasanya Perda yang dibentuk oleh pemerintahan daerah dapat dibatalkan oleh kekuasaan yang lebih tinggi dalam sistem hukum kenegaraan di Indonesia. Persoalan executive review dan judicial review menjadi semakin jelas pasca Putusan Mahkamah Konstitusi Putusan MK Nomor 137/ PUU-XIII/2015 dan Nomor 56/PUU-XIV/2016. Putusan tersebut menentukan bahwa Pemerintah Pusat tidak lagi memiliki kewenangan executive review terhadap Perda kabupaten/kota, karena kewenangan tersebut 'dikembalikan sepenuhnya kepada Mahkamah Agung. Kendatipun demikian, Putusan ini tidaklah menegasikan kewenangan executive review Pemerintah pusat terhadap peraturan kepala daerah serta tidak menghilangkan kewenangan untuk melakukan executive preview. Sebagai pelaksanaan atas putusan tersebut, Pemerintah telah menerbitkan Peraturan Menteri Dalam Negeri Republik Indonesia Nomor 120 Tahun 2018 Tentang Perubahan Atas Peraturan Menteri Dalam Negeri Nomor 80 Tahun 2015 Tentang Pembentukan Produk Hukum Daerah.

53 Ibid. h. 99.

54 Putusan Mahkamah Agung Nomor: 66 P/HUM/2018, h. 2.

55 Ibid. h. 36.

56 Ibid. h. 73. 


\section{DAFTAR PUSTAKA}

\section{$\underline{\text { Buku }}$}

Fadjar, A. M. (2004). Penyelenggaraan Pemerintahan yang Baik dan Demokratis dalam Konteks Negara Hukum Indonesia Tipe Negara Hukum. Cetakan Pertama. Malang: Bayumedia Publishing

Seidman, A. et.al. (2002). Penyusunan Rancangan Undang-Undang Dalam Perubahan Masyarakat Yang Demokratis: Sebuah Panduan untuk Pembuat Rancangan Undangundang. Diterjemahkan oleh: Yohanes Usfunan, dkk. Edisi Kedua, Proyek Elips II, Jakarta: Departemen Kehakiman dan HAM Republik Indonesia.

Amrusyi, F. (1987). Otonomi Dalam Negara Kesatuan. Abdurrahman (Ed.). Jakarta: Media Sarana Press.

Suseno, F. M. (1997). Mencari Sosok Demokrasi - Sebuah Telaah Filosofis. Jakarta: Gramedia.

Asshidiqqie, J. (2009). Menuju Negara Hukum Yang Demokratis. Jakarta: Bhuana Ilmu Populer.

Ridwan, J. \& Sudrajat, A. S. (2009). Hukum Administrasi Negara. Bandung: Nuansa

Rasjidi, L. \& Rasjidi, I. T. (2002). Pengantar Filsafat Hukum, Bandung,: Mandar Maju.

Fuady, M. (2010). Konsep Negara Demokrasi. Bandung: Refika Aditama.

Ridwan, H. R. (2006). Hukum Administrasi Negara. Jakarta: Raja Grafindo Persada.

\section{Jurnal}

Akhmad Khalimy. (2017) Pencabutan Peraturan Daerah Dalam Timbangan Negara Hukum, Mahkamah, 2(1). doi: http://Dx.Doi.Org/10.24235/Mahkamah.V2i1.1617

Leo Agustino. 2017. Pembatalan 3.143 Peraturan Daerah: Satu Analisis Singkat. CosmoGov, 3(1). doi: https:// doi.org/10.24198/cosmogov.v3i1.12405

Muhammad Reza Winata, Mery Christian Putri, \& Zaka Firma Aditya. Legal Historis Kewenangan Pengujian Dan Pembatalan Peraturan Daerah Serta Implikasinya Terhadap Kemudahan Berusaha. Jurnal Rechtsvinding. 7(3), 335-352.

Novira Maharani Sukma. (2017). Analisis Yuridis Pembatalan Perda oleh Menteri Dalam Negeri. Jurnal Ilmiah Galuh Yustisi. 5(1).

Santoso, S. (2014). Pembentukan Peraturan Daerah Dalam Era Demokrasi. Refleksi Hukum: Jurnal Ilmu Hukum, 8(1). doi: https://Doi.Org/Https://Doi.Org/10.24246/Jrh.2014.V8.I1.P1-18

Sholikin, M. Nur. (2017). Penghapusan Kewenangan Pemerintah Untuk Membatalkan Perda; Momentum Mengefektifkan Pengawasan Preventif Dan Pelaksanaan Hak Uji Materiil MA, Rechtsvinding Online (12 Mei 2017). 
Sihombing, Eka N. A. M. (2017). Perkembangan Kewenangan Pembatalan Peraturan Daerah Dan Peraturan Kepala Daerah: Kajian Putusan Mahkamah Konstitusi Nomor 137/PUU-XIII/2015 dan Nomor 56/PUU-XIV/2016. Jurnal Yudisial, 10(2).

Wahyu Tri Hartomo. (2018). Implikasi Putusan Mahkamah Konstitusi Nomor 137/PUU-XIII/2015 Dan Putusan Nomor 56/PUU-XIV/2016 Tentang Pembatalan Perda Provinsi, Perda Kabupaten/Kota, Peraturan Gubernur, Dan Peraturan Bupati/Peraturan Walikota. Jurnal Legislasi Indonesia, 15 (2).

Yuswanto dan M. Yasin Al Arif, Diskursus Pembatalan Peraturan Daerah Pasca Putusan MK No. 137/PUU-XIII/2015 dan No. 56/PUU-XIV/2016. Jurnal Konstitusi. 15(4).

\section{$\underline{\text { Karya Ilmiah dan Paper }}$}

A.Hamid S. Attamimi, 1992, Teori Perundang-Undangan Indonesia, "Pidato" Pada Upacara Pengukuhan Jabatan Guru Besar Tetap Di Fakultas Hukum UI, Jakarta, 25 April 1992.

I Nyoman Suyatna, "Penyelenggaraan Pemerintahan Yang Baik Dan Demokratis Dalam Konteks Negara Hukum Indonesia", Paper disampaikan dalam Focus Group Discussion Kelompok Kerja Analisis dan Evaluasi Hukum Terkait Tata Kelola Pemerintahan, dengan tema: "Tata Kelola Pemerintahan yang Efektif, Efisien, Transparan, Akuntabel dan Demokratis, diselenggarakan oleh Pusat Analisis dan Evaluasi Hukum Nasional, Badan Pembinaan Hukum Nasional Kementerian Hukum dan HAM bekerjasama dengan Kantor Wilayah Kementerian Hukum dan HAM Provinsi Bali, pada hari Kamis, 28 Maret 2019, di Hotel Grand Inna Kuta, Bali

Satjipto Rahardjo, 2008, UUD 1945 Sebagai Landasan Grand Design Sistem Dan Politik Hukum Nasional, Pokok-Pokok Pikiran Penyaji - Sesi II, Dalam "Konvensi Hukum Nasional Tentang Undang-Undang Dasar 1945 Sebagai Landasan Konstitusional Grand Design System Dan Politik Hukum Nasional", Diselenggarakan Oleh Badan Pembinaan Hukum Nasional Departemen Hukum Dan HAM, Jakarta, 1516 April 2008.

\section{$\underline{\text { Peraturan Perundang-undangan }}$}

Undang-Undang Dasar Negara Republik Indonesia Tahun 1945

Undang-Undang Nomor 12 Tahun 2011 Tentang Pembentukan Peraturan PerundangUndangan, Lembaran Negara Republik Indonesia Tahun 2011 Nomor 82.

Undang-Undang Nomor 23 Tahun 2014 Tentang Pemerintahan Daerah, Lembaran Negara Republik Indonesia Tahun 2014 Nomor 244.

Peraturan Mahkamah Agung Republik Indonesia Nomor 1 Tahun 2011 Tentang Hak Uji Materiil 
Peraturan Menteri Dalam Negeri No. 80 Tahun 2015 tentang Pembentukan Produk Hukum Daerah, Berita Negara Republik Indonesia Tahun 2015 Nomor 2036.

Peraturan Menteri Dalam Negeri Republik Indonesia Nomor 120 Tahun 2018 Tentang Perubahan Atas Peraturan Menteri Dalam Negeri Nomor 80 Tahun 2015 Tentang Pembentukan Produk Hukum Daerah, Berita Negara Republik Indonesia Tahun 2018 Nomor 157

Instruksi Mendagri Nomor: 582/476/SJ tentang Pencabutan/Perubahan Peraturan Daerah, Peraturan Kepala Daerah, dan Keputusan Kepala Daerah yang Menghambat Birokrasi dan Perizinan Investasi, tanggal 16 Februari 2016.

Instruksi Mendagri Nomor: 582/1107/SJ tentang Penegasan Instruksi Mendagri Nomor: 582/476/SJ tentang Pencabutan/Perubahan Peraturan Daerah, Peraturan Kepala Daerah, dan Keputusan Kepala Daerah yang Menghambat Birokrasi dan Perizinan Investasi, tanggal 4 April 2016

\section{Putusan Pengadilan}

Putusan Mahkamah Agung Nomor: 64 P/HUM/2017

Putusan Mahkamah Agung Nomor: 66 P/HUM/2018

Putusan Mahkamah Konstitusi Nomor 137/PUU-XIII/2015

Putusan Mahkamah Konstitusi Nomor 56/PUU-XIV/2016

Putusan Mahkamah Konstitusi Nomor 66/PUU-XIV/2016

\section{$\underline{\text { Internet }}$}

Fabian Januarius Kuwado. (2016). "Jokowi: 3.143 Perda Bermasalah Telah Dibatalkan". Retrieved from https://nasional.kompas.com/read/2016/06/13/17215521/jokowi.3.143.perda. bermasalah.telah.dibatalkan, diakses 13 Juni 2016.

Lutfy Mairizal Putra. (2017). Tjahjo Tak Habis Pikir MK Cabut Kewenangan Mendagri Batalkan Perda. Retrieved from https://Nasional.Kompas.Com/Read/2017/04/06/10561981/Tjahjo.Tak.H abis.Pikir.Mk.Cabut.Kewenangan.Mendagri.Batalkan.Perda, 6 April 2017.

Imanuel Nicolas Manafe. (2017). Pemerintah Hormati Putusan MK Terkait Kewenangan Pencabutan Perda. Retrieved from http://www.Tribunnews.Com/Nasional/2017/04/07/Pemerintah-HormatiPutusan-Mk-Terkait-Kewenangan-Pencabutan-Perda, diakses 7 April 2017.

Hukumonline. (2017). MK Tegaskan Mendagri Masih Boleh Batalkan Perda Provinsi. Retrieved from https://Www.Hukumonline.Com/Berita/Baca/Lt58eb3eaf51dd2/MkTegaskan-Mendagri-Masih-Boleh-Batalkan-Perda-Provinsi, diakses 10 April 2017. 